\title{
The Influence of Fuel/Oxygen Ratio in HVOF Spraying on the Deposition of $\mathrm{Cr}_{3} \mathrm{C}_{2}$ Coatings
}

\author{
Byoung Hee Kim and Dong Soo Suhr \\ Department of Materials Engineering, Chungnam National University, \\ 220 Gung-dong, Yuseong-gu, Teajon 305-764, Korea
}

This study was performed to investigate the influence of fuel/oxygen ratio $(\mathrm{F} / \mathrm{O}=3.2,3.0,2.8)$ on the characteristics of the HVOF sprayed $\mathrm{Cr}_{3} \mathrm{C}_{2}$ (7 mass\% NiCr) coatings after heat treatment up to $1000^{\circ} \mathrm{C}$. Decomposition and oxidation of the $\mathrm{Cr}_{3} \mathrm{C}_{2}$ occurred during spraying. The degree of decomposition from $\mathrm{Cr}_{3} \mathrm{C}_{2}$ to $\mathrm{Cr}_{7} \mathrm{C}_{3}$ was increased with decreasing the $\mathrm{F} / \mathrm{O}$ ratio. The micro-structural differences of the as-sprayed coatings with $\mathrm{F} / \mathrm{O}$ ratio cannot be distinguished. However, large pores were diminished and then the coatings became dense by heat treatment. Micro-hardness of the as-sprayed coating which is sprayed with $\mathrm{F} / \mathrm{O}=3.0$ condition was the highest $\left(\mathrm{Hv}_{300}=1140\right)$ and the hardness was increased to 1660 after heat treatment at $1000^{\circ} \mathrm{C}$ for $50 \mathrm{~h}$ in air. It was supposed that hardness was increased due to the formation of $\mathrm{Cr}_{2} \mathrm{O}_{3}$ within the $\mathrm{Cr}_{3} \mathrm{C}_{2} / \mathrm{Cr}_{7} \mathrm{C}_{3}$ matrix and the densification of the coating layer during heat treatment. Mass loss of the as-sprayed coating by erosion varied from 79 to $80.8 \mathrm{mg}$ depending on $\mathrm{F} / \mathrm{O}$ ratio and varied from 47.2 to $49 \mathrm{mg}$ after heat treatment at $600^{\circ} \mathrm{C}$. Erosion resistance of the coating was improved about $40 \%$ after heat treatment at $600^{\circ} \mathrm{C}$. It is concluded that improvement of erosion resistance of the coatings was due to production of the coatings with a very dense microstructure, high cohesive strength and a very high hardness value by heat treatment.

(Received March 29, 2000; Accepted November 6, 2000)

Keywords: high velocity oxy-fuel (HVOF) sprayed $\mathrm{Cr}_{3} \mathrm{C}_{2}$ (7 mass\%NiCr) coatings, decomposition, fuel/oxygen ratio, erosion

\section{Introduction}

WC-Co and $\mathrm{Cr}_{3} \mathrm{C}_{2}-\mathrm{NiCr}$ coatings are used for a wide range of applications. ${ }^{1-3)}$ The hardness of $\mathrm{WC}-\mathrm{Co}$ coating is higher than that of $\mathrm{Cr}_{3} \mathrm{C}_{2}-\mathrm{NiCr}$ coating, but WC-Co coating has low thermal expansion coefficient $\left(6 \times 10^{-6}{ }^{\circ} \mathrm{C}^{-1}\right)$, poor oxidation and corrosion resistance. ${ }^{4)}$ Therefore, WC-Co coating is not used as a hard-facing coating above $650^{\circ} \mathrm{C}$. However, $\mathrm{Cr}_{3} \mathrm{C}_{2}$ coating serves as protection against wear and erosion such as compressor blades, compressor stator vane and bearing housing at high temperature up to $900^{\circ} \mathrm{C}$ in spite of the relatively low hardness of coating because it is inexpensive and thermal expansion coefficient $\left(9.3-11 \times 10^{-6}{ }^{\circ} \mathrm{C}^{-1}\right)$ of $\mathrm{Cr}_{3} \mathrm{C}_{2}$ is very similar to that of iron $\left(12 \times 10^{-6}{ }^{\circ} \mathrm{C}^{-1}\right) .{ }^{5,6)}$

Hybrid-HVOF spray system has been developed to apply premium turbine engine coatings. ${ }^{7)}$ The hybrid-HVOF gun system does not solely rely on water-cooling but also air assisted, whereas conventional HVOF gun system depends on only water-cooling. Therefore, heat loss of hybrid system is much lower than that of conventional HVOF system. And also hybrid gun system produces gas velocity up to $2100 \mathrm{~m} / \mathrm{s}$ and produces higher particle velocity. ${ }^{7)}$ Accordingly, the sprayed coatings are dense and can get higher hardness than those by plasma spraying method. Generally, combustion fuels used in HVOF thermal spraying include propylene, acetylene, propane, hydrogen and kerosene. Coating properties, such as microstructure, phases and mechanical properties, depend on fuel used for HVOF thermal spraying and fuel/oxygen ratio. ${ }^{8,9)}$

This study is performed to investigate the influence of hydrogen/oxygen ratio $(\mathrm{F} / \mathrm{O}=3.2,3.0,2.8)$ on the characteristics (microstructure, phases, hardness and erosion resistance) of the hybrid-HVOF sprayed $\mathrm{Cr}_{3} \mathrm{C}_{2}(7$ mass $\% \mathrm{NiCr})$ and also to investigate characteristics after the heat treatment up to $1000^{\circ} \mathrm{C}$.

\section{Experimental Procedure}

Carbon steel was used as substrate. The specimen size was $\Phi 25 \mathrm{~mm} \times t 5 \mathrm{~mm}$. The surface of substrate was blasted with 80-mesh alumina grit after degreasing at $250^{\circ} \mathrm{C}$ for $1 \mathrm{~h}$ and cleaning with acetone. The average surface roughness $(\mathrm{Ra})$ of substrate was $4.15 \mu \mathrm{m}$ after blasting. Powder in which $\mathrm{Cr}_{3} \mathrm{C}_{2}$ and $\mathrm{NiCr}$ was mechanically mixed in a ratio of 93 to 7 mass\% was used with commercial powder (Metco, Diamalloy 3005). Spraying conditions were shown at Table 1. Gas combination was based on the standard condition recommended by manufacturers of the commercial powder. ${ }^{10)} \mathrm{Hy}$ drogen flow rate was $681 \mathrm{slpm}$ constantly and oxygen flow rate was varied at 215, 229 and $243 \mathrm{slpm}$. Hydrogen/oxygen ratio was consequently $3.2,3.0$ and 2.8 . Characteristics of sprayed coatings were observed after heat treatment at $600^{\circ} \mathrm{C}, 800^{\circ} \mathrm{C}$ and $1000^{\circ} \mathrm{C}$ for $50 \mathrm{~h}$ in air. Microstructure was observed with SEM (Hitachi S-2350). Pore size and pore size distribution of the coatings were made by mercury intrusion method with Micromeritics Pore Sizer 9305. Phase analysis of the coatings was studied with XRD using monochromatized $\mathrm{CuK} \alpha$ radiation at $40 \mathrm{~kW}$ and $80 \mathrm{~mA}$. Scanning range was $2 \theta=30-60^{\circ}$. Micro-hardness of the

Table 1 HVOF spraying conditions.

\begin{tabular}{cccc}
\hline $\begin{array}{c}\text { Hydrogen flow rate } \\
\text { (SLPM) }\end{array}$ & $\begin{array}{c}\text { Oxygen flow rate } \\
\text { (SLPM) }\end{array}$ & $\begin{array}{c}\mathrm{H}_{2} / \mathrm{O}_{2} \\
\text { ratio }\end{array}$ & $\begin{array}{c}\text { Air flow rate } \\
\text { (SLPM) }\end{array}$ \\
\hline \multirow{4}{*}{681} & 215 & 3.2 & \\
& 229 & 3.0 & 361 \\
& 243 & 2.8 & \\
\hline \multirow{2}{*}{ Other conditions: Gun-to-work distance } & $: 200 \mathrm{~mm}$ & \\
& Rotating speed & $: 221 \mathrm{~m} / \mathrm{min}$ \\
& Gun traverse rate & $: 7.8 \mathrm{~m} / \mathrm{min}$ \\
\hline
\end{tabular}


coatings was obtained from cross-sectional specimens by the micro-Vickers hardness tester (Digital Micro Hardness Tester MXT- $\alpha 7$; Matsuzawa) with a load $300 \mathrm{~g}$ for $10 \mathrm{~s}$. In order to compare a relative erosion rate of the coatings depending on fuel/oxygen ratio, erosion was tested at room temperature, an erodent velocity of $60 \mathrm{~m} / \mathrm{s}$, an impingement angel of $30^{\circ}$, erodent feeding of $10 \mathrm{~g} / \mathrm{min}$ and duration time of $30 \mathrm{~min}$ after heat treatment up to $800^{\circ} \mathrm{C}$ for $50 \mathrm{~h}$ in air. Erosion rate was determined by sample mass loss divided by the mass of the erodent. The erodent was an angular 80-mesh alumina. The nozzle for the erosion tester was made from 304 stainless steel tube of $6.35 \mathrm{~mm}$ outside diameter and $4.72 \mathrm{~mm}$ internal diameter. Erodent particles were placed in the airfloating particle hopper that feeds the particles into a nozzle, $500 \mathrm{~mm}$ in length, directed vertically downward at the specimen. More detailed description of the erosion apparatus is given in reference. ${ }^{11)}$

\section{Results and Discussion}

Figure 1 shows the SEM micrograph (a) and particle size distribution (b) of the $\mathrm{Cr}_{3} \mathrm{C}_{2}(7 \mathrm{mass} \% \mathrm{NiCr})$ powder. The powder consists of irregular shaped $\mathrm{Cr}_{3} \mathrm{C}_{2}$ and $\mathrm{NiCr}$ mixed mechanically. The average particle size was $15.9 \mu \mathrm{m}$ and particle size distribution ranges from 5 to $50 \mu \mathrm{m}$.

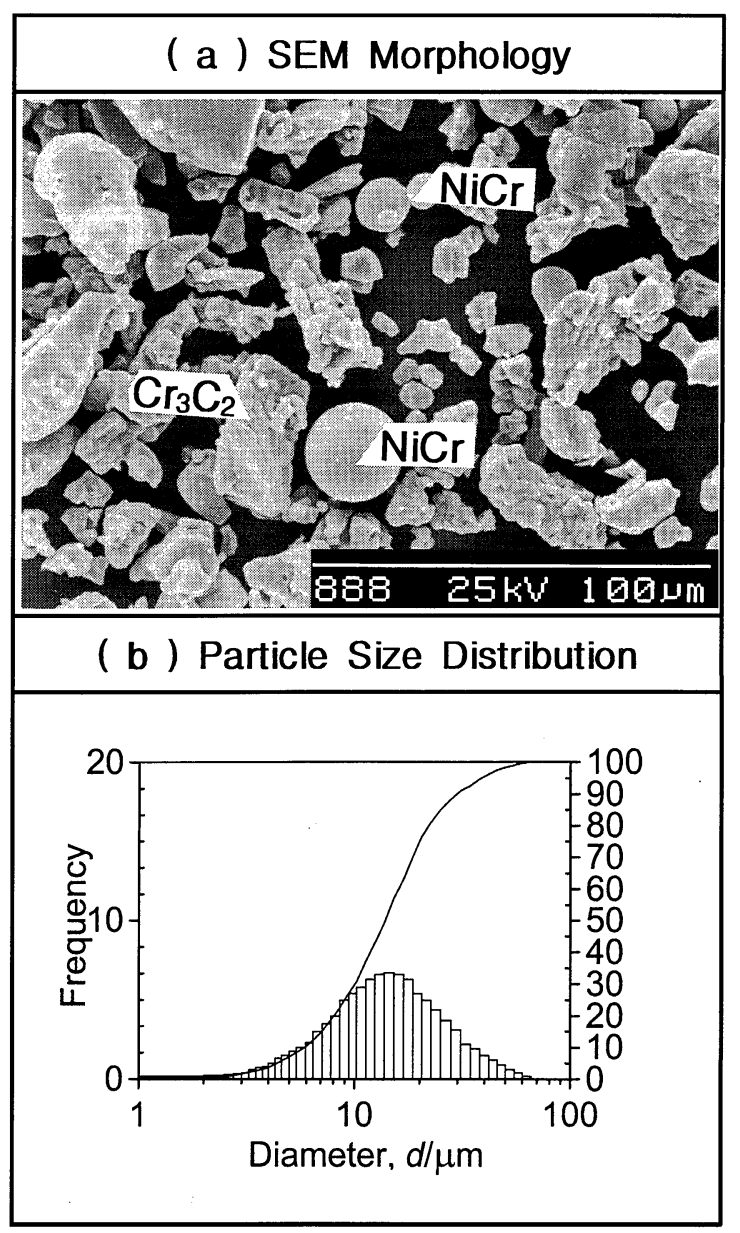

Fig. 1 SEM morphology (a) particle size distribution (b) of the $\mathrm{Cr}_{3} \mathrm{C}_{2}$ (7 mass $\% \mathrm{NiCr}$ ) powder.
Figure 2 shows the SEM micrograph and pore size distribution of the as-sprayed coatings depending on hydrogen/oxygen ratio (indicate as F/O ratio). The micro-structural differences of the as-sprayed coatings according to $\mathrm{F} / \mathrm{O}$ ratio cannot be externally distinguished. However, the pore size and pore size distribution were different according to the $\mathrm{F} / \mathrm{O}$ ratio. The micro-pores under $1 \mu \mathrm{m}$ and large pores over $10 \mu \mathrm{m}$ were also observed in coating at $\mathrm{F} / \mathrm{O}=3.2$ condition. And at the $\mathrm{F} / \mathrm{O}=3.0$ condition, the mezzo-pores below $10 \mu \mathrm{m}$ was distributed. And also, a lot of pores over $1 \mu \mathrm{m}$ and large-pores over $10 \mu \mathrm{m}$ were observed at the $\mathrm{F} / \mathrm{O}=2.8$ condition.

Figure 3 is a plot showing the porosity change of the coatings depending on the $\mathrm{F} / \mathrm{O}$ ratio. The porosity of the coating was varied from 0.69 to $0.99 \%$ depending on the F/O ratio. And the porosity of the coating, as shown in Fig. 3, was the highest at $F / O=2.8$ condition and was the lowest at the $\mathrm{F} / \mathrm{O}=3.0$ condition. Accordingly, we found that the porosity of the coating was influenced by $\mathrm{F} / \mathrm{O}$ ratio. The reason is that F/O ratio has an effect on the lamellae structure of the coating because flame temperature and gas velocity were directly controlled by $\mathrm{F} / \mathrm{O}$ ratio. ${ }^{10,12)}$ Typically the flame temperature increases as the fuel/oxygen ratio decreases and the gas velocity increases as the fuel/oxygen ratio increases, and also high flame temperature is produced when the fuel/oxygen ratio comes closer to stoichiometric ratio (2 in terms of volume). ${ }^{13)}$ Consequently, by investigating the effect of the F/O ratio on porosity of the coating, we found that the $\mathrm{F} / \mathrm{O}=3.0$ condition was the optimal condition for hybrid-HVOF thermal spraying of $\mathrm{Cr}_{3} \mathrm{C}_{2}(7$ mass $\% \mathrm{NiCr})$ powder in the range of this study. Indeed, $\mathrm{F} / \mathrm{O}=3.0$ condition was superior to other conditions not only in porosity but also in hardness and erosion resistance of the coating.

Figure 4 is SEM images showing fracture morphologies and pore size distribution of the as-sprayed coating sprayed with $\mathrm{F} / \mathrm{O}=3.0$ after heat treatment at $600^{\circ} \mathrm{C}$ and $800^{\circ} \mathrm{C}$ for $50 \mathrm{~h}$ in air. The splats in as-sprayed coating were clearly distinguished but the splats became gradually indistinct with increasing heat-treating temperature from 600 to $800^{\circ} \mathrm{C}$. And also the pores ranging from 0.03 to $0.8 \mu \mathrm{m}$ perfectly disappeared after heat treatment at $600^{\circ} \mathrm{C}$. Furthermore, the pores under $5 \mu \mathrm{m}$ were conspicuously increased but the pores over $8 \mu \mathrm{m}$ were not observed after heat treatment at $800^{\circ} \mathrm{C}$.

Figure 5 is a plot showing the porosity of the coating depending on heat-treating temperature. The porosity of the coating was linearly decreased with increasing heat-treating temperature. It was believed that a conspicuous reduction of the porosity was due to densification of the coating resulting from a sintering effect by heat treatment.

Figure 6 shows XRD patterns of the powder and the coatings sprayed with $\mathrm{F} / \mathrm{O}=3.0$ after heat treatment at 600,800 and $1000^{\circ} \mathrm{C}$ for $50 \mathrm{~h}$. Main phases of the powder consisted of $\mathrm{Cr}_{3} \mathrm{C}_{2}$ and $\mathrm{NiCr}$ binder and also $\mathrm{Fe}_{2} \mathrm{O}_{3}$ was observed. After HVOF-spraying, main phase of the coating, as shown in Fig. 6, was $\mathrm{Cr}_{7} \mathrm{C}_{3}$ phase. And also a small amount of $\mathrm{Cr}_{2} \mathrm{O}_{3}$ was observed but $\mathrm{NiO}$ was not observed. Generally, phases in the as-sprayed coating consist of $\mathrm{Cr}_{3} \mathrm{C}_{2}, \mathrm{Cr}_{7} \mathrm{C}_{3}, \mathrm{Cr}_{23} \mathrm{C}_{6}$ and $\mathrm{Cr}_{2} \mathrm{O}_{3}$ but it is difficult to exactly distinguish $\mathrm{Cr}_{23} \mathrm{C}_{6}$ from the XRD pattern because of overlapping of diffraction line of several carbide phases and $\mathrm{NiCr}$ binder. ${ }^{12,14)} \mathrm{Cr}_{7} \mathrm{C}_{3}$ and $\mathrm{Cr}_{23} \mathrm{C}_{6}$ 


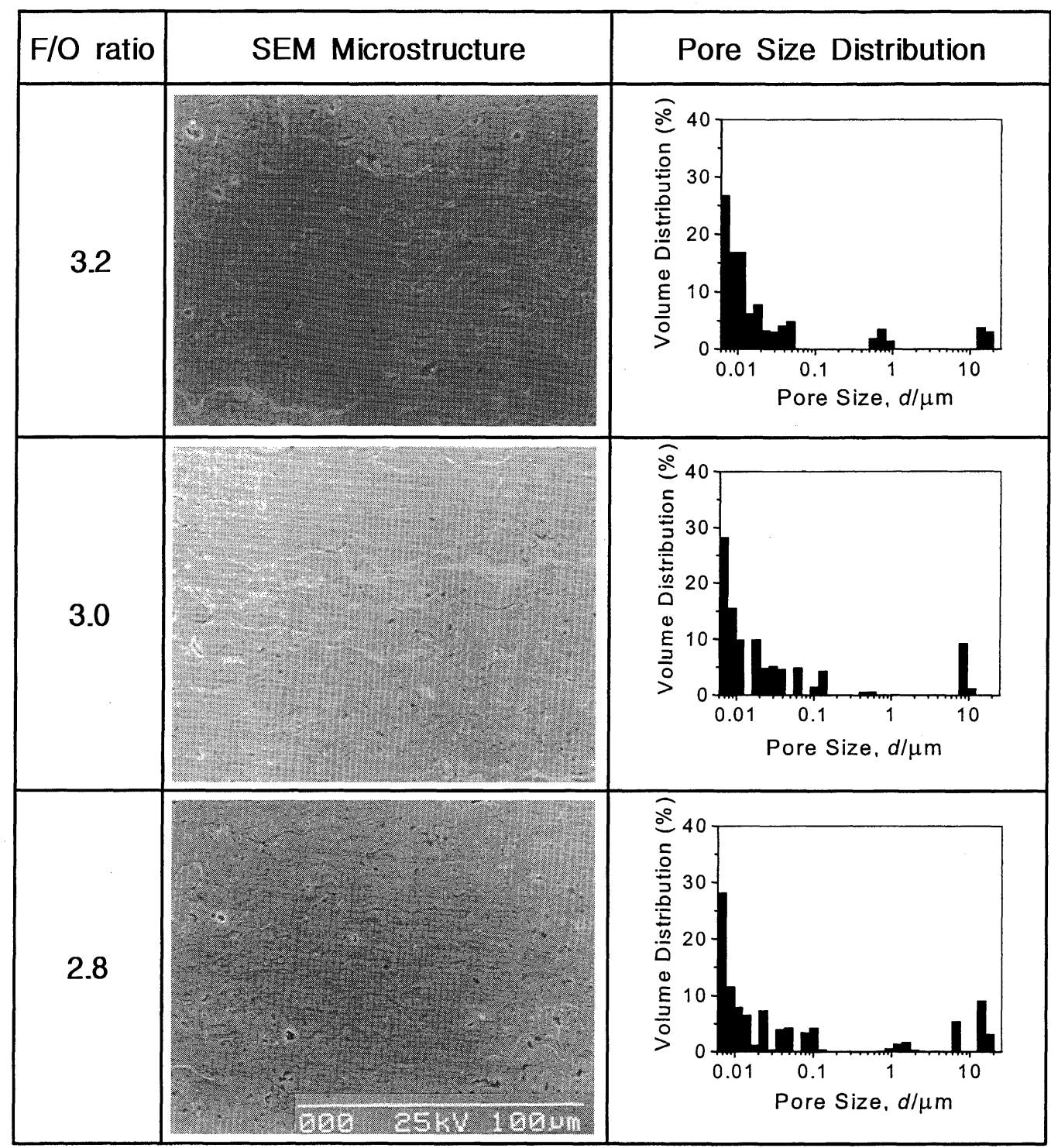

Fig. 2 SEM microstructure and pore size distribution of the coatings depending on F/O ratio.

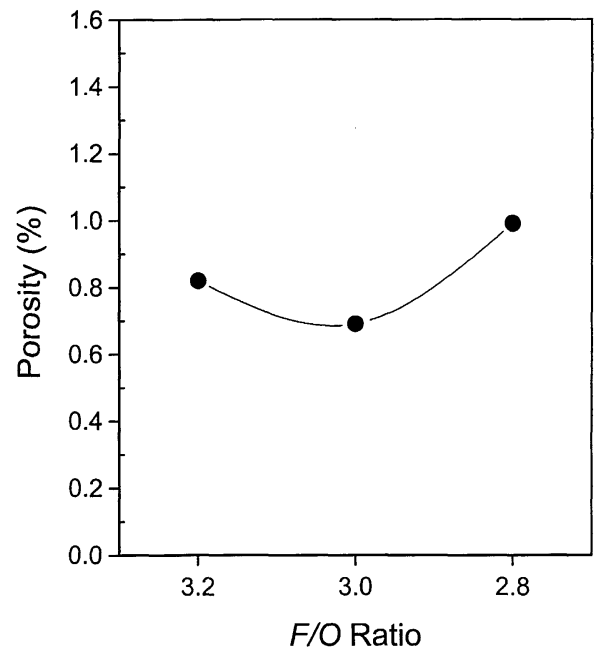

Fig. 3 Porosity change of the as-sprayed coatings depending on F/O ratio. phase may occur by decomposition of the $\mathrm{Cr}_{3} \mathrm{C}_{2}$ during spraying. However, $\mathrm{Cr}_{23} \mathrm{C}_{6}$ phase seems not to be present in this study. The amount of decomposition is influenced by flame temperature and local oxidation potential. After heat treatment at $600^{\circ} \mathrm{C}$, intensity of $\mathrm{Cr}_{7} \mathrm{C}_{3}$ (151) plane was abruptly increased whereas intensity of $\mathrm{Cr}_{7} \mathrm{C}_{3}$ (112) plane was decreased. $\mathrm{NiO}$ was observed at a nearby 37 and $43.5^{\circ}$ and also a complex $\mathrm{NiCr}_{2} \mathrm{O}_{4}$ oxide was observed nearby $30^{\circ}$ after heat treatment at $800^{\circ} \mathrm{C}$.

Figure 7 is a plot showing the relative intensity ratio obtained from $\mathrm{Cr}_{3} \mathrm{C}_{2}$ (121) and $\mathrm{Cr}_{7} \mathrm{C}_{3}$ (222) after Gaussian fitting with $\mathrm{Cr}_{3} \mathrm{C}_{2}$ (121) and $\mathrm{Cr}_{7} \mathrm{C}_{3}$ (222) plane in order to investigate decomposition rate of the coatings depending on $\mathrm{F} / \mathrm{O}$ ratio and heat treatment. Decomposition rate from $\mathrm{Cr}_{3} \mathrm{C}_{2}$ to $\mathrm{Cr}_{7} \mathrm{C}_{3}$ was the lowest at $\mathrm{F} / \mathrm{O}=3.2$, whereas it was the highest at $\mathrm{F} / \mathrm{O}=2.8$. It means that flame temperature at $\mathrm{F} / \mathrm{O}=3.2$ (approximately $2070^{\circ} \mathrm{C}$ ) was relatively lower than flame temperature at $\mathrm{F} / \mathrm{O}=3.0$ (approximately $2097^{\circ} \mathrm{C}$ ) and $\mathrm{F} / \mathrm{O}=2.8$ (approximately $2180^{\circ} \mathrm{C}$ ). ${ }^{13)}$ And decomposition of $\mathrm{Cr}_{3} \mathrm{C}_{2}$ was 


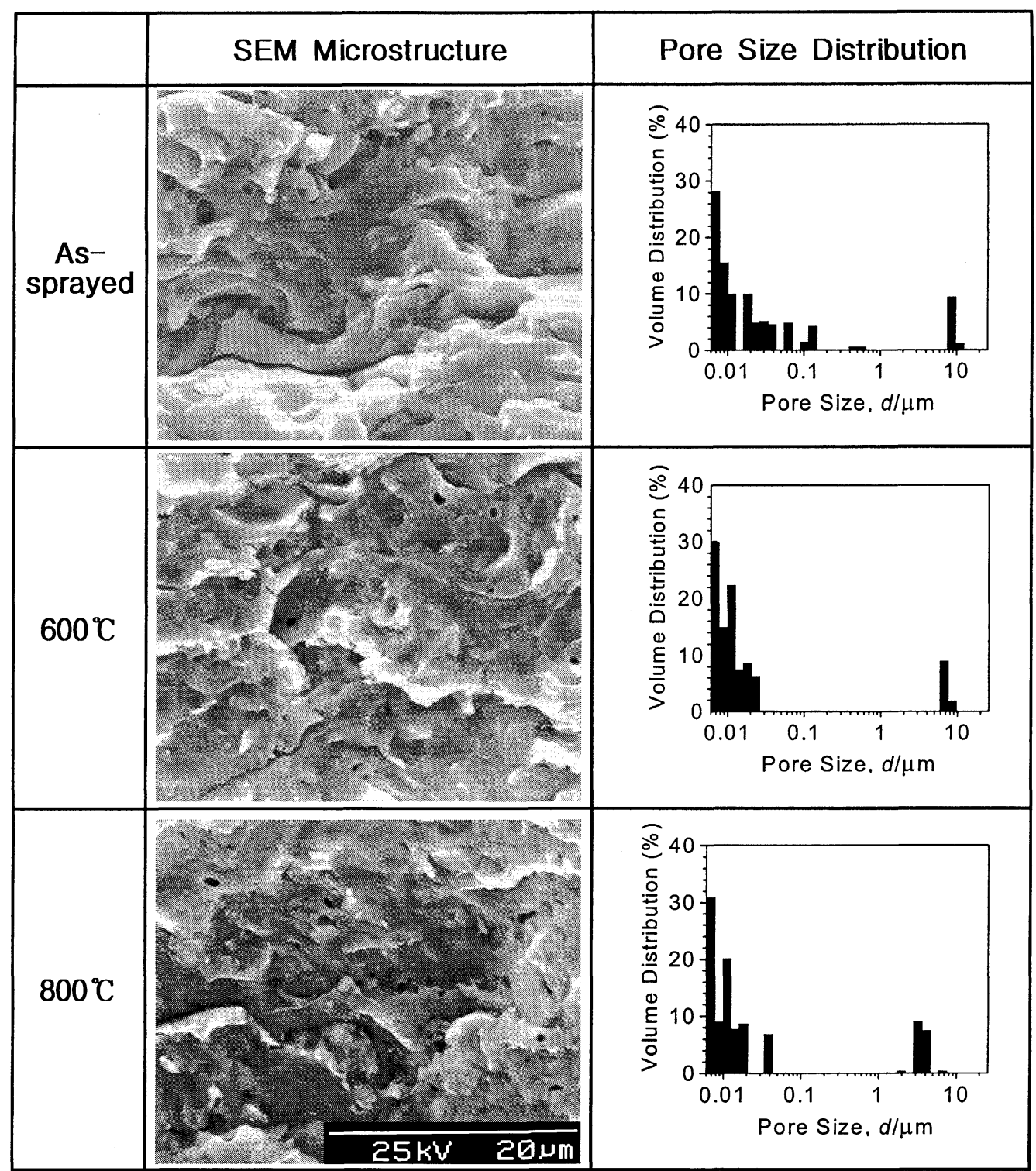

Fig. 4 SEM microstructure and pore size distribution of the coating at $\mathrm{F} / \mathrm{O}=3.0$ depending on heat-treating temperature.

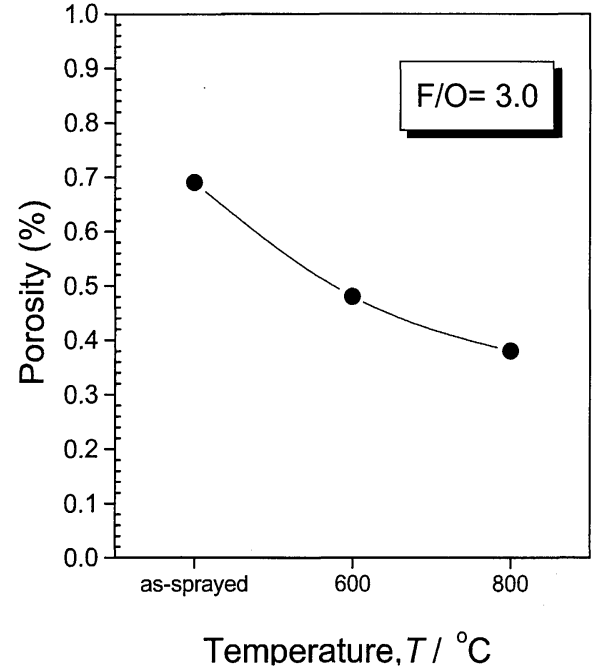

Fig. 5 Porosity change of the coating $(\mathrm{F} / \mathrm{O}=3.0)$ depending on heat-treating temperature. accelerated with decreasing F/O ratio. Generally, decomposition rate increases when flame temperature increases and the fuel/oxygen ratio comes closer to stoichiometric ratio. ${ }^{13)}$ And after heat treatment up to $800^{\circ} \mathrm{C}$, decomposition of the coating gently occurred at $\mathrm{F} / \mathrm{O}=3.2$ but linearly occurred at $\mathrm{F} / \mathrm{O}=3.0$ and $\mathrm{F} / \mathrm{O}=2.8$ by oxidation reaction. However, after heat treatment at $1000^{\circ} \mathrm{C}$, as shown in Fig. 7, the fraction of $\mathrm{Cr}_{3} \mathrm{C}_{2}$ phase at $\mathrm{F} / \mathrm{O}=3.0$ and $\mathrm{F} / \mathrm{O}=2.8$ was similar to that of $800^{\circ} \mathrm{C}$, whereas the fraction of $\mathrm{Cr}_{3} \mathrm{C}_{2}$ phase at $\mathrm{F} / \mathrm{O}=3.2$ was decreased below $10 \%$. From these results, we found that the $\mathrm{F} / \mathrm{O}$ ratio had an important effect on oxidation behavior of the sprayed $\mathrm{Cr}_{3} \mathrm{C}_{2}$ coating. And oxidation behavior of the $\mathrm{Cr}_{3} \mathrm{C}_{2}$ coating depending on $\mathrm{F} / \mathrm{O}$ ratio is going to be reported.

Figure 8 is a plot showing the average micro-hardness values of the coating depending on F/O after heat treatment up to $1000^{\circ} \mathrm{C}$. The micro-hardness value of as-sprayed coatings was from 1099 to 1140 with F/O ratio. Micro-hardness of the as-sprayed coating sprayed with $\mathrm{F} / \mathrm{O}=3.0$ condition 


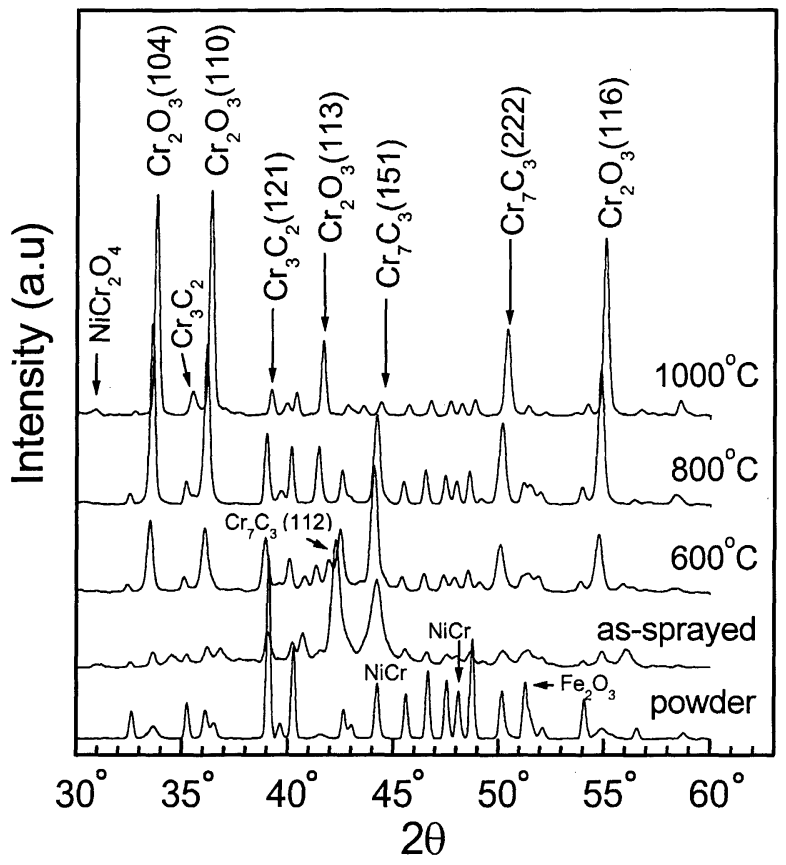

Fig. 6 XRD patterns of the powder and the coating $(F / O=3.0)$ depending on heat-treating temperature.

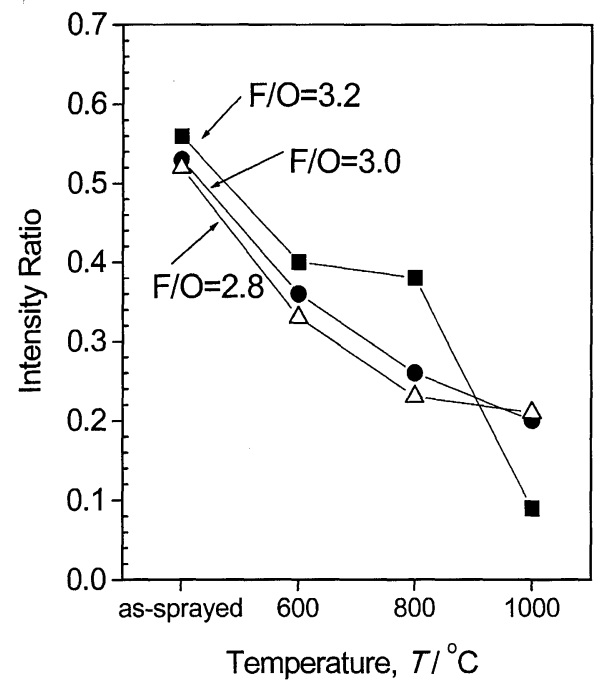

Fig. 7 XRD intensity ratio of $\mathrm{Cr}_{3} \mathrm{C}_{2}$ to $\mathrm{Cr}_{7} \mathrm{C}_{3}$ depending on heat-treating temperature.

was the highest, which was $\mathrm{Hv}_{300}=1140$. And also the micro-hardness value was increased by 300-400 depending on $\mathrm{F} / \mathrm{O}$ ratio after heat treatment at $600^{\circ} \mathrm{C}$. In the case of $\mathrm{F} / \mathrm{O}=3.0$ condition, the micro-hardness value was significantly increased up to 1500 . It was supposed that hardness was increased due to the densification of the coating layer by sintering effect during heat treatment $600^{\circ} \mathrm{C} .{ }^{11)}$ And also after heat treatment at $800^{\circ} \mathrm{C}$, the hardness was not greatly different from that at $600^{\circ} \mathrm{C}$ but after heat treatment at $1000^{\circ} \mathrm{C}$, though it was somewhat different with $\mathrm{F} / \mathrm{O}$ ratio, hardness of $\mathrm{F} / \mathrm{O}=3.0$, as shown in Fig. 8, was increased up to 1660 . It is believed that the coating formed oxide/carbide composite due to the formation of $\mathrm{Cr}_{2} \mathrm{O}_{3}$ within $\mathrm{Cr}_{3} \mathrm{C}_{2} / \mathrm{Cr}_{7} \mathrm{C}_{3}$ matrix by

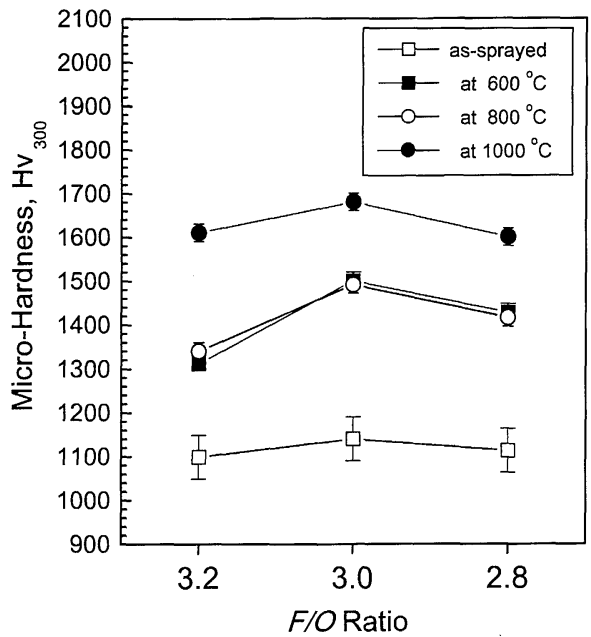

Fig. 8 Micro-Vickers hardness of the coatings depending on F/O ratio.

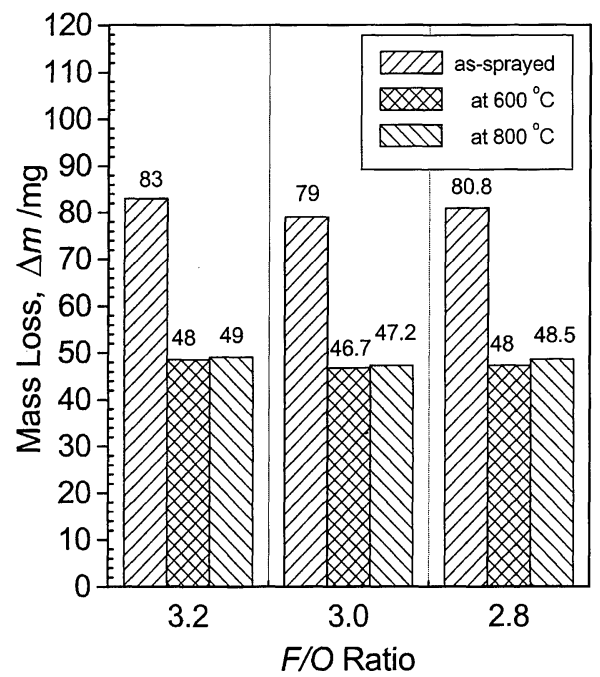

Fig. 9 Mass loss of the coatings depending on F/O ratio.

internal oxidation of the coating layer. ${ }^{5)}$

Figure 9 is a plot showing mass loss of the coating with impingement angle of $30^{\circ}$ and $\mathrm{Al}_{2} \mathrm{O}_{3}$ erodent velocity of $60 \mathrm{~m} / \mathrm{s}$ in order to study erosion resistance of the coating depending on $\mathrm{F} / \mathrm{O}$ after heat treatment to $800^{\circ} \mathrm{C}$. Mass loss of the assprayed coating at $\mathrm{F} / \mathrm{O}=3.2$ was $83 \mathrm{mg}$ and also mass loss at $\mathrm{F} / \mathrm{O}=3.0$ and $\mathrm{F} / \mathrm{O}=2.8$ was 79 and $80.8 \mathrm{mg}$, respectively. Accordingly, mass loss of the coating seems to be directly related to hardness value of the as-sprayed coating but to be of no relevance to the pore size and pore size distribution of the coating. And also mass loss of the coating was greatly decreased with increasing heat-treating temperature. Erosion resistance of the coating was improved about $40 \%$ after heat treatment at $600^{\circ} \mathrm{C}$ regardless of $\mathrm{F} / \mathrm{O}$ ratio. And erosion resistance after heat treatment at $800^{\circ} \mathrm{C}$ was slightly decreased than that after heat treatment at $600^{\circ} \mathrm{C}$. In conclusion, it is concluded that improvement of erosion resistance of the coatings was due to production of the coating with a very dense microstructure, high cohesive strength and a very high hardness value by heat treatment. Regretfully, because the speci- 
men was not able to be attached to erosion tester by the severe oxidation of the substrate after heat treatment at $1000^{\circ} \mathrm{C}$ for $50 \mathrm{~h}$, the erosion resistance at $1000^{\circ} \mathrm{C}$ could not be compared with other temperature conditions.

\section{Conclusion}

The characteristics of HVOF sprayed $\mathrm{Cr}_{3} \mathrm{C}_{2}$ ( 7 mass $\% \mathrm{NiCr}$ ) coatings depending on hydrogen/oxygen ratio are summarized as follows.

(1) The porosity of the coating was the lowest at $\mathrm{F} / \mathrm{O}=$ 3.0 ratio and linearly decreased with increasing heat-treating temperature.

(2) The decomposition in as-sprayed coating, regardless of the $\mathrm{F} / \mathrm{O}$ ratio, occurred from $\delta-\mathrm{Cr}_{3} \mathrm{C}_{2}$ phase to $\beta-\mathrm{Cr}_{7} \mathrm{C}_{3}$ phase but $\mathrm{Cr}_{23} \mathrm{C}_{6}$ phase was clearly not distinguished. And decomposition rate was the highest at the $\mathrm{F} / \mathrm{O}=2.8$ ratio.

(3) The micro-hardness value of as-sprayed coatings was varied from 1099 to 1140 with F/O ratio. Micro-hardness of the as-sprayed coating sprayed with $\mathrm{F} / \mathrm{O}=3.0$ condition was the highest, which was $\mathrm{Hv}_{300}=1140$. After heat treatment at $1000^{\circ} \mathrm{C}$, though it was somewhat different with $\mathrm{F} / \mathrm{O}$ ratio, hardness of $\mathrm{F} / \mathrm{O}=3.0$ was increased up to 1660 .

(4) Mass loss of the as-sprayed coating at $\mathrm{F} / \mathrm{O}=3.2$ was $83 \mathrm{mg}$ and also mass loss at $\mathrm{F} / \mathrm{O}=3.0$ and $\mathrm{F} / \mathrm{O}=2.8$ were 79 and $80.8 \mathrm{mg}$, respectively. And erosion resistance of the coating was improved about $40 \%$ after heat treatment at $600^{\circ} \mathrm{C}$. It is concluded that improvement of erosion resistance of the coatings was due to production of the coatings with a very dense microstructure, high cohesive strength and a very high hardness value by heat treatment.

\section{REFERENCES}

1) H. R. Eschnauer and O. Knotek: Thin Solid Film, 45 (1977), 287-294.

2) O. Knotek: Thin Solid Film, 95 (1982), 209-217.

3) S. Rangaswamy: Ph. D. Dissertation, State University of New York, (1987).

4) J. F. Lynch, C. G. Ruderer and W. H. Duckworth: Engineering Properties of Selected Ceramic Material, The American Ceramic Society, Inc. (1966).

5) P. Schwarzkope and R. Kieffer: Cemented Carbide, The Macmillan Company, New York (1960), pp. 178-190.

6) D. W. Parker and Gerald L. Kutner: Advanced Materials and Processes, 4/91 (1991), 68-74.

7) Metco, Hybrid HVOF Gun System, (1994).

8) G. Y. Lai: Thin Solid Films, 53 (1978), 343-351.

9) H. Kreye, R. Schwetzke and S.Zimmermann: Thermal Spray: Practical Solution for Engineering Problems, ed. by C. C Berndt Proceedings of the 9th National Thermal Spray Conference 7-11 Oct. Cincinnati, (1996), pp. 451-456.

10) Metco, Hybrid-Diamond jet 2600 Technical Note, (1992).

11) B. H. Kim and D. S. Suhr: Korean J. Mater. Res., 7(11) (1997), 934 941.

12) Taylor T. A. M. P. Overs, J. M. Quets and R. C. Tucker: Thin Solid Film, 107 (1983), 249-435.

13) K. Korpiola and P. Vuoristo: Thermal Spray: Practical Solution for Engineering Problems, ed. by C. C Berndt Proceedings of the 9th National Thermal Spray Conference 7-11 Oct. Cincinnati, (1996), pp. 177-184.

14) Y. A. Kharlamov: Mater. Sci. Eng., 93 (1987), 1-37. 